Prepared for: The Year's Work in Modern Language Studies, Vol. 73 (survey year 2011; to appear in 2013).

\title{
[TT]French Studies*
}

\section{[TT]Language and Linguistics}

\section{[A]By Paul Rowlett, University of Salford}

\section{[H2]1. General}

The University of Oradea (Rumania) has launched Studii de Lingvistică, whose first issue, ed. Estelle Moline and Daciana Vlad, is dedicated to Maria Țenchea and reflects her research interests in Fr., containing contributions on syntax (prepositions, pronouns, gerunds, quantifiers), discourse ananlysis, and translation. *Martin Vol. contains the proceedings of a March 2011 event in Metz and crosses semantics and lexicography. Berrendonner Vol. contains 43 articles covering morphosyntax, syntax, semantics, pragmatics, discourse, reference, standardization, and semiology.

\section{[H2]2. History of the Language}

L. Zaring, 'On the Nature of OV and VO Order in Old French', Lingua, 121:1831-52, argues, on the basis of similarities between OV order in OF and in West Germanic languages, that OF was typologically OV, uses antisymmetry to account for OV order initially in periphrastic constructions and then in infinitival clauses, and suggests that instances of $\mathrm{VO}$ are due to 
competition between an older OV grammar and a newer VO one. D. Arteaga, 'On Bare Subject Relative Clauses in Old French', LSRL40, pp. 99-116, offers a Minimalist analysis of OF restrictive relatives like Car ne voi tertre nen soeit rases 'For I see no small hill (that) is not razed to the ground', which unlike modern Fr. allow the relative pronoun qui to be null. Also within Minimalism, C. M. Salvesen, 'Stylistic Fronting and Remnant Movement in Old French', Going Romance 2009, pp. 323-42, offers an analysis of OF and Mid. Fr. stylistic fronting of both a head (infinitive dire 'say' or faire 'do') together with a phrase (complement or adverb) on the basis of remnant movement and vP-internal scrambling. E. Oppermann-Marsaux, 'Les Emplois du marqueur discursif "di va" en ancien français', Discours (online), 8, focuses on three specific areas, namely, the freezing of $d i$ va in comparison with $v a+d i$, the growing pragmatic function of imperative $d i$, and the function/position of di va within indirect speech, seeing di va as a polysemous discourse marker, sometimes retaining the core meaning of dire, sometimes not. M. Troberg, 'From Indirect to Direct Object: Systematic Change in 15th-Century French', Diachronica, 28:382-422, argues that the syntactic development of, e.g., aider à qqn to aider qqn 'to help s.o.' fails to parallel any semantic or selectional change, but is part of an array of changes in verbal complementation, e.g., the loss of directionality as a feature of Fr. prepositions. See also T.'s 'Directed Motion in Medieval French', LSRL40, pp. 117-36, which contrasts satellite-framed med. Fr. (directed motion encoded via manner verbs and telic-goaldenoting PP complements) and verb-framed contemporary Fr. (directed motion encoded via path verbs and adjoined manner phrases), sees the contrast within a broader constellation of typological properties, and attributes it to the extended functional projection of Ps, which in med. but not modern Fr. permit simple prepositions to encode path. M. Zimmermann and G. A. Kaiser, 'Much Ado about Nothing? On the Categorial Status of et and ne in Medieval French', Corpus, 9:265-90, argue that, despite apparent distributional problems, a unique analysis of et as a co-ordinating conjunction and of ne as the clitic counterpart of non is to be preferred. See 
also K. and Z.'s 'On the Decrease in Subject-Verb Inversion in French Declaratives', Meisel Vol., pp. 355-81, which rejects the V2 analysis of subject-verb inversion in declarative root clauses in med. Fr. and instead explains the phenomenon by differentiating between 'true' subject-verb inversion and 'NP inversion' and invoking a 'Focus Criterion'. Medieval Multilingualism: The Francophone World and its Neighbours, ed. Christopher Kleinhenz and Keith Busby, Turnhout, Brepols, viii +323 pp., contains an introduction and 14 further articles. T. M. Rainsford, 'Dividing Lines: The Changing Syntax and Prosody of the Mid-line Break in Medieval French Octosyllabic Verse', TPS, 109:265-83.

M.-B. Mosegaard Hansen, *'A Pragmatic Approach to Historical Semantics, with Special Reference to Markers of Clausal Negation in Medieval French', pp. 233-57 of Methods in Historical Semantics, ed. Kathryn Allan and Justyna A. Robinson, Berlin, de Gruyter, viii +347 pp., discusses the role of pragmatic inferencing in semantic change, with illustration from English and Fr., and a comparative analysis of the emergence and development of the negative particles pas, mie, and point in med. French. P. Larrivée, 'The Role of Pragmatics in Grammatical Change: The Case of French Preverbal Non', JP, 43:1987-96, considers the role of pragmatics in the diachronic development known as Jespersen's cycle, in particular the evolution of preverbal negative non, which categorically marks pragmatic activation with finite verbs in OF, but loses this value with non-finite verbs in Mid. Fr., a change which leads to its decline as it competes with the well-established default ne ... pas. V. Déprez, 'From $\mathrm{N}$ to $\mathrm{D}$ : Charting the Time Course of the Internal Rise of French N-words', pp. 257-80 of The Noun Phrase in Romance and Germanic: Structure, Variation, and Change, ed. Petra Sleeman and Harry Perridon, Amsterdam, Benjamins, vii +283 pp., reviews the feature composition and changing modification properties of Fr. n-words to map out their internal syntactic structure and the course of their internal rise within the nominal projection, identifying precise steps which directly relate internal structural changes to changes in concord properties, and supporting the 
hypothesis that it was change in the internal structure of n-words that brought about the current properties of negative concord rather than changes in the negation marker. The Evolution of Negation: Beyond the Jespersen Cycle, ed. Pierre Larrivée and Richard Ingham, Berlin, de Gruyter, vi +350 pp., contains six articles based on a thematic series of seminars held in Birmingham, UK in 2008-2009, and six more or less direct 'replies' to them. There is much here of interest to Fr. (and AN) scholars, in particular pieces by M. Labelle, R. Ingham, F. Martineau, P. Rowlett, V. Déprez, and M.-B. Mosegaard Hansen.

R. Ingham, 'Grammar Change in Anglo-Norman and Continental French: The Replacement of Non-affirmative Indefinite Nul by Aucun', Diachronica, 28:441-67, counters the conventional view that later AN was moribund, isolated from mainstream Fr., and extensively calqued on English, arguing instead that it was largely grammatically independent. On the basis of mainland and insular administrative documents from 1250-1425 Ingham shows how AN followed med. Fr. in allowing aucun to replace nul first in non-assertive and then in negative clauses in a way unrelated to the syntax of indefinite expressions in Mid. English. Id., 'AngloNorman and the "Plural History" of French: The Connectives Pourtant and A cause que', Revue Française de Linguistique Appliquée, 16:107-19, provides textual evidence from electronic corpora that pourtant and à cause que appear in AN with their modern meanings much earlier than standardly assumed, and suggests insights into spatial and register variation and semantic-pragmatic change over time.

W. Ayres-Bennett and M. Seijido, 'Les Compilations raisonnées des Remarques et Observations sur la langue française', FS, 65:347-56, use three 17 th/18th-c. case studies to investigate how metalinguistic comment has lost its sociolinguistic dimension relating to variation and change as a consequence of being compiled in a different format, retaining merely its normative force. See also A.-B. and S.'s Remarques et Observations sur la langue française: histoire et évolution d'un genre, Garnier, $348 \mathrm{pp}$. 
R. King et al., 'The Interplay of Internal and External Factors in Grammatical Change:

First-person Plural Pronouns in French', Language, 87:470-509, review four centuries of fictional dialogue, metalinguistic commentary, and naturalistic data, as well as (extra)linguistic conditioning factors, to reconsider whether the modern dominance of the 1PL proform on results from fairly rapid change in the late 19 th/early 20 th c., or goes back several centuries. They offer quantitative and qualitative analysis not only of on and nous usage but also the usually neglected, lower-class use of je in combination with -ons, and show that the shift toward dominant on takes place in the late 19th c. in lower-class speech, but not until the 20th c. among the upper classes, and that the lower-class usage moves from je to on via nous. G. Quentel, *'La Néologie expressive et onomatopéique dans l'étymologie du français', RevR, 46:89-104, uses Fr. examples to reject the onomatopoeic approach to historically unexplained words, and suggests alternative approaches to unresolved Fr. etymologies.

S. Gómez-Jordana, 'L'Évolution diachronique des adverbes justement/justamente, apparemment/aparentement, décidément/decididamente en français et en espagnol', VR, 69, 2010:206-31. C. Howe and D. L. Ransom, 'The Evolution of Clausal Temporal Modifiers in Spanish and French', RPh, 64:197-208. J. Lindschouw, 'L'Évolution du système du futur du moyen français au français moderne: La Réorganisation comme un cas de régrammation', RLiR, 75(297-298):51-97.

\section{[H2]3. Phonetics and Phonology}

*LaF, no. 169, 'Phonologie du français contemporain', ed. Bernard Laks, includes articles covering the elision of liquids, schwa, and liaison. JFLS, no. 21.1:1-110, 'La Prosodie française: Regards croisés sur la prosodie du français: Des données à la modélisation', ed. Mathieu Avanzi and Elisabeth Delais-Roussarie, based on a 2009 Paris workshop, contains an 
Introduction by the editors and 5 articles. M.-H. Côté, 'French Liaison', vol. 5, pp. 2685-710 of The Blackwell Companion to Phonology, ed. Marc van Oostendorp et al., Oxford, Wiley-Blackwell, 5 vols, $3192 \mathrm{pp}$., sets out the challenges posed by Fr. liaison to linguistic analysis.

A. Bürki et al., 'What Affects the Presence versus Absence of Schwa and its Duration: A Corpus Analysis of French Connected Speech', The Journal of the Acoustical Society of America, 130:3980-91, show that only 5 of 17 claimed factors appear to condition variant choice in a radio corpus of over 4000 tokens of words with variants with and without schwa, and that only two of these also predict schwa duration. They conclude that the variants without schwa do not result from a phonetic process of reduction but are, instead, generated early in the production process. See also Id., 'Phonetic Reduction versus Phonological Deletion of French Schwa: Some Methodological Issues', JPh, 39:279-88, which similarly paints a more complex picture than the traditional account of the Fr. schwa zero alternation, based on a categorical phonological-deletion process, resulting in two discrete outputs: forms with schwa and forms without. Like other segments in Fr., schwa undergoes phonetic reduction, and some schwa-less tokens in connected speech may consequently result from gradual phonetic reduction rather than categorical alternation. F. Torreira and M. Ernestus, 'Vowel Elision in Casual French: The Case of Vowel/e/ in the Word C'était', ib.:50-8, investigate the reduction of /e/ in c'était /sete/ 'it was', and find that it is acoustically absent in over half the occurrences of the word in a corpus of casual Fr., and that [e] length and complete elision are conditioned by different factors. C. Meunier and R. Espesser, 'Vowel Reduction in Conversational Speech in French: The Role of Lexical Factors', ib.:271-8, examine vowel length and quality and show clearly that vowel reduction (shortening and centralization) affects most vowels in conversational speech, more so in non-word-final than word-final syllables, and in monosyllabic function words than monosyllabic content words, while word frequency has no clear affect on vowel length, and 
several lexical and prosodic factors affect vowel reduction. M. Adda-Decker and N. D. Snoeren, 'Quantifying Temporal Speech Reduction in French Using Forced Speech Alignment', ib.:261-70, use large spoken corpora covering different speech styles (broadcast news; telephone and face-to-face conversations) to investigate variation in length reduction and elision, and highlight the increasing impact of speech reduction with less formal, more spontaneous and interactive speaking styles.

Selected Proceedings of the 5th Conference on Laboratory Approaches to Romance Phonology, ed. Scott M. Alvord, Somerville, Cascadilla, 164 pp., contains C. L. Smith, 'Acoustic Correlates of Listener-identified Boundaries in Spontaneous French Speech' (142-52) and C. M. Stewart, 'On the Anatomy of a Prosodic Sociolinguistic Marker in Parisian French' (108-17). Z. Fagyal and C. M. Stewart, 'Prosodic Style-shifting in Pre-adolescent Peer-group Interactions in a Working-class Suburb of Paris', pp. 75-99 of Ethnic Styles of Speaking in European Metropolitan Areas, ed. Friederike Kern and Margret Selting, Amsterdam, Benjamins, vi +321 pp., contrast the pragmatically neutral rising/falling phrase-final intonation used by male adolescents from a multi-ethnic working-class suburb of Paris when listing words prompted by visual stimuli with the characteristic rising-falling intonation attributed to working-class youth vernacular in contact with immigrant languages used when negotiating the interpretation of pictures or competing with friends for the floor, and argue that in working-class youth vernacular phrase-final rising-falling intonation seems to function as a micro-level style feature indexing common ground and in-group affiliation with members of the adolescent peer group. Z. Fagyal, 'Rhythm Types and the Speech of Working-class Youth in a Banlieue of Paris: The Role of Vowel Elision and Devoicing', pp. 91-132 of A Reader in Sociophonetics, ed. Dennis R. Preston and Nancy Niedzielski, Berlin, de Gruyter, 2010, iv + 426 pp.

O. Niebuhr et al., 'On Place Assimilation in Sibilant Sequences: Comparing French and English', JPh, 39:429-51, conduct parallel Fr./English acoustic analyses of voiced/voiceless 
(post)alveolar sibilants that can occur across word boundaries, as well as the individual (post)alveolar sibilants combined with preceding/following labial consonants across word boundaries, and find clear evidence for place assimilation in both languages. Yet while in English the assimilation was strictly regressive and primarily towards postalveolar, in Fr. it was solely towards postalveolar, but both regressive and progressive. See also O. Niebuhr and C. Meunier, 'The Phonetic Manifestation of French /s\#J/ and / $\#$ \#/ Sequences in Different Vowel Contexts: On the Occurrence and the Domain of Sibilant Assimilation', Phonetica, 68:133-60, which finds that /i, a, u/ preceding / $/$ / are longer, breathier, less intense, and have more cardinal $\mathrm{F} 2$ values than before /s/, and that in /s\# $\int /$ and /J\#s/ environments regressive and progressive /s/-to-[]] assimilation was (despite common assumptions) complete in terms of spectral centreof-gravity measurements (although vowels preceding /s\# $/$ still reflect /s/).

F. Torreira and M. Ernestus, 'Realization of Voiceless Stops and Vowels in Conversational French and Spanish', Laboratory Phonology, 2:331-53, identify significant differences in the realization of intervocalic voiceless stops, and vowels surrounded by voiceless stops, in the two languages, with voiceless stops tending to have shorter stop closures, displaying incomplete closures more often, and exhibiting more voicing in $\mathrm{Sp}$. than in Fr., and with vowels demonstrating more cases of complete devoicing and greater degrees of partial devoicing in Fr. than in Spanish. L. Colantoni and J. Steele, *'Synchronic Evidence of a Diachronic Change: Voicing and Duration in French and Spanish Stop-Liquid Clusters', CanJL, $56: 147-77$

*Intonational Phrasing in Romance and Germanic: Cross-linguistic and Bilingual Studies, ed. Christoph Gabriel and Conxita Lleó, Amsterdam, Benjamins, viii + 237 pp., contains C. Féry et al., 'Correlates of Phrasing in French and German from an Experiment with Semispontaneous Speech' (11-41), which on the basis of a methodology involving speakers asked to describe orally the spatial arrangement of toy animals on a table shows clearly that prosodic 
phrasing correlates to syntactic structure in both languages, but that tonal excursions correspond to pitch accents and boundaries in Ger. while having a demarcative function in Fr., a difference explained by the presence/absence of lexical stress in the two languages, and B. Post, 'The Multi-facetted Relation between Phrasing and Intonation Contours in French' (43-74), which uses prosodic variation to test the claim that the connections between the grouping of words in an utterance, the distribution of accents within those groups, and the intonation contours that can all be realized can be successfully formalized in the grammar, and reports the results of a production experiment confirming that speech rate affects the frequency distribution and phonetic implementation of prosodic structures, but not the underlying system of phonological forms, as expected since one of the crucial predictions is that the same grammar underlies any variation in prosodic surface forms that can be observed at, for instance, different speaking rates.

J.-D. Gendron, 'L’Accent québécois révélateur du double style de prononciation pratiqué à Paris aux XVIle et XVIIle siècles et de l'origine de l'accent bourgeois du XIXe siècle', FM, 79:129-56. A. B. Hansen and C. Juillard, 'La Phonologie parisienne à trente ans d'intervalle: Les Voyelles à double timbre', JFLS, 21:313-59, review a body of work going back to the early 1940s on the collapse in northern Fr. of four vocalic phoneme distinctions into allophonic pairs (/e/-/ع/ parlé-parlait; /ø/-/œ/ jeûne-jeune; /o/-/っ/ saute-sotte; /a/-/a/ mâle-mal) which demonstrates that increasingly few speakers distinguish between the two /A/s and /E/s, with intermediate vowel quality found where a distinction would be expected, with the other two pairs being affected to a lesser extent. E. Russell Webb, 'Accounting for R: Shifting Segments and Constraint-based Grammar', LSc, 33:90-106, endeavours to formalize in constraint-based models segmental shifts shown in historic Fr. data on rhotics, using productive and perceptual evaluative matrices to account for output variability, and a formalization of ranked output. M. Avanzi, 'La Dislocation à gauche en français spontané: Étude instrumentale', $F M, 79: 157-75$, 
undertakes a corpus study to investigate the received wisdom that the end of an LD'ed constituent is prominent, and hypotheses why stress is not always found. B. Genç et al., 'Pausing Preceding and Following Que in the Production of Native Speakers of French', Canadian Journal of Applied Linguistics, 14:144-54, show that native speakers have significantly longer pauses before than after complementizer que when reading passages out loud, but that the contrast is reversed in spontaneous speech.

\section{[H2]4. Morphology}

Defective Paradigms: Missing Forms and What they Tell us, ed. Matthew Baerman et al., OUP, 2010, 230pp., contains: G. Boyé and P. Cabredo Hofherr, 'Defectiveness as Stem Suppletion in French and Spanish Verbs' (35-52) and M. Rezac 'Ineffability Through Modularity: Gaps in the French Clitic Cluster' (151-80). M. Barra-Jover, 'Comment Évolue Un Trait grammatical: Le Pluriel en français dans une perspective romane', RPh, 63, 2009:25-67. A. Patard and A. Richard, 'Attenuation in French Simple Tenses', Cahiers Chronos, 22:157-78. See also P.'s 'L'Imparfait dans le tour [(et) si IMP ?]', Revue de Sémantique et Pragmatique, 25-26, 2009:223-42. G. Palumbo and G. Roques, 'L'Infinitif absolu passé', RLiR, 75(297-298):5-50. M. Becker, 'Passé composé versus passé simple: Alles passé?', RF, 122, 2010:3-27, uses Houellebecq's Extension du domaine de la lutte to show how the semantic contrast between the perfect and the past-historic constructs temporal relations within the narrative thread.

\section{[H2]5. Syntax}

E. Doron and M. Labelle, 'An Ergative Analysis of French Valency Alternations', LSRL40, pp. 137-54, distinguish between the two Fr. anticausative constructions, one of which focuses on 
the result (Res-AC; Le rameau s'est flétri), the other, on the process (Proc-AC; Le rameau a flétri) (both $\simeq$ 'The branch withered'), by claiming that Res-AC results from the merge of se under non-active Voice and the absence of a vP projection, while Proc-AC results from the use of active Voice and a specifier-less v projection. Meanwhile Steffen Heidinger, ${ }^{*}$ French Anticausatives: A Diachronic Perspective, Berlin, de Gruyter, 2010, viii + 205 pp., considers the emergence and spread of new ways of encoding valence alternations, and their impact on existing patterns, and focuses on the two anticausative members of the Fr. causativeanticausative alternation (La branche s'est cassée vs. La branche a cassé 'The branch broke'). See also G. Fotiadou and H. Vassiliadou, *'Interprétation(s) des verbes anticausatifs en grec et en français: Liens entre fréquence et données empiriques', $\operatorname{TrL}, 62: 99-127$.

D. Sportiche, 'French Relative Qui', LI, 42:83-124, approaches the que/qui alternation on the basis not of constraints on subject extraction but rather on a double paradigm of weak and strong wh elements, similar to the strong/weak pronominal system. J.-M. Authier, 'A Movement Analysis of French Modal Ellipsis', Probus, 23:175-216, argues that modal ellipsis is syntactically derived by movement of the TP to topic position followed by PF deletion on the basis of its discourse recoverability. T. O'Neill, 'The Syntax of $\mathrm{Ne}$. . que Exceptives in French', University of Pennsylvania Working Papers in Linguistics, 17:175-84, offers a Minimalist analysis of sentences like Je ne lis que le journal 'I don't read anything but the newspaper' which, in the spirit of lexical economy, and despite their atypical distribution, assumes no special status for ne or que, instead relating the construction to the syntax of a reduced clausal comparative, whereby the exception phrase following que is the remnant of an elliptical relative clause adjoined to an optionally covert NPI. A. Zribi-Hertz, 'Definite DPs without Lexical Nouns in French: Clausal Modifiers and Relativization', Going Romance 2009, pp. 363-90. H. Werner, 'Verbflexion und funktionale Kategorien im Französischen', FLin, 30, 2010:177-214, rejects standard V-raising, I-lowering, and split-Infl accounts of Fr. finite and infinite clauses on the 
grounds of 'serious conceptual defects', and offers an alternative non-transformational analysis based on several assumptions relating to functional categories, Infl, the merger of inflected verbs, feature geometry, head movement, predicate modifiers, and nominative case assignment.

Jan Lindschouw, *Étude des modes dans le système concessif en français du $16 e$ au 20e siècle et en espagnol moderne: Évolution, Assertion et Grammaticalisation, Copenhagen, Museum Tusculanum, 297 pp., studies the development of the mood system in 16th-20th-c. Fr. concessive clauses from the perspective of grammaticalisation theory in the sense of grammarinternal reorganization, and illustrates how usage of the subjunctive has progressively narrowed, while usage of the indicative has broadened. Comparison with Sp. casts doubt on the general assumption that Romance languages form a continuum from conservative to innovative varieties. K. Hunnius, 'Der französische Konjunktiv aus der Sicht der (historischen) Soziolinguistik', ZRP, 125, 2009:127-37, argues that the long-standing suspicion that the Fr. subjunctive is moribund and in retreat is a consequence of the overwhelming linguistic importance attached to the spoken language to the detriment of the status of the written form where there is no sign of crisis.

A. Zribi-Hertz, 'Pour Un Modèle diglossique de description du français: Quelques Implications théoriques, didactiques et méthodologiques', JFLS, 21:231-56, argues that contemporary $\mathrm{Fr}$. is characterized by diglossia, with a standard $\mathrm{H}$ variety sitting alongside informal dialectal $L$ varieties, and that speakers' competence should be encoded by two intersecting grammars. See also P. Rowlett, 'Syntactic Variation and Diglossia in French', Salford Working Papers in Linguistics and Applied Linguistics, 1:13-26, which considers the status of stable variation with respect to the mental grammars of speakers, in particular in the light of Massot's work suggesting that contemporary metropolitan Fr. is characterized by diglossia, and argues that Massot's model needs to be revised in order to allow surface forms to 
have a different status in each of the underlying grammars.

Mairi McLaughlin, Syntactic Borrowing in Contemporary French: A Linguistic Analysis of News Translation, Oxford, Legenda, xii + 136 pp., draws on fieldwork conducted in an international news agency and a corpus of translated news-agency dispatches to test the widely held assumption that the scale of translation of news copy out of English will lead to changes in Fr. syntax, and to investigate how news translation can lead to syntactic borrowing. Id., 'When Written is Spoken: Dislocation and the Oral Code', JFLS, 21:209-29, uses a mixed-medium spoken/journalistic/literary corpus to refine the link between dislocated constructions and the spoken language and to show how the form/function of dislocations vary by 'level of orality' and how conveying orality does not always seem to be the primary motivation for dislocation.

Proceedings of the 28th West Coast Conference on Formal Linguistics, ed. Mary Byram Washburn et al., Somerville, Cascadilla, 322 pp., contains N. Boneh and L. Nash, 'High and Higher Applicatives: The Case of French Non-core Datives' (60-68), H. Burnett, 'A Unified Semantic Analysis of the Licensing Conditions of "Bare" Nouns in French' (78-86), and V. Homer, 'French Modals and Perfective: A Case of Aspectual Coercion' (106-14). P. Lauwers, 'The Modification of Predicative Bare nouns in French: A Functional Analysis', TPS, 109:12-40, contains a corpus-based study of the modification patterns of predicative bare nouns in Fr. (e.g Je suis bon catholique 'I am a good Catholic') which aims to illuminate the available modification patterns in semantic-functional terms.

E. Moline, 'Comme distraction les devoirs c'est barbant: Les Constructions disloquées en $(X)$ c'est Adj comme N', JFLS, 21:401-15, describes a structure usually thought to characterize spontaneous spoken language, finds it also in writing, and analyses it in terms of three elements ( $X, c^{\prime}$ 'est $A d j$, and comme $N$ ), whereby in writing comme $N$ is often used to restrict the applicability of the assessment ( $X, c^{\prime}$ est $\left.A d j\right)$, whereas in spoken language it can be used to identify the referent of ce. M. Mossberg, *'L'Emploi du gérondif et de la construction V1 
och V2 dans l'incise: Étude contrastive français-suédois', RevR, 46:1-41, uses a corpus of translated literary texts to compare Fr. and Sw. inserted parenthetical clauses appearing after a direct quotation, namely the Fr. gérondif and the Sw. V1 och V2 construction in contexts such as dit-elle en souriant / sa hon och log, and argues for typologically contrasting functions/uses: exocentric Fr. hierarchically considering the different aspects of a communicative situation according to their importance; endocentric Sw. linearly dividing the communicative situation into successive actions. F. Hamlaoui, 'On the Role of Phonology and Discourse in Francilian French Wh Questions', JL, 47:129-62, argues that in Francilian Fr., the dialect spoken in the Paris metropolitan area, in situ and fronted-wh questions have the same answerhood conditions but vary with respect to their respective focus-set, a difference which lies in the discourse status of their non-wh portion which may or may not be discourse-given, depending on the discourse context. $\mathrm{H}$. then uses OT and stress alignment to motivate sentence-final wh phrases. L. Gosselin, 'L'Aspect de phase en français: Le Rôle des périphrases verbales', JFLS, 21:149-71, argues that aspectual periphrases (e.g., commencer à, être en train de) should be divided into two types depending on whether they refer to a genuine sub-process or merely indicate an aspectual perspective. K. Van Goethem, *'From Adjective to Affix in Dutch and French: The Influence of Word Order Patterns on Grammaticalization', StLa, 35:194-216, shows on the basis of parameters such as de-/re-semanticization and decategorization how the grammaticalization of lexemes into affixes, in particular the development of adjectives into affixes (prefix or suffix), e.g., oud- 'old', dol- 'mad', nouveau- 'new', -vriendelijk 'friendly', is more productive and more advanced in Dutch than in Fr. and that the difference is related to modifier-head ordering. J. Giry-Schneider, “'L’Expression de la quantité approximative en français: Les Adjectifs de quantité (ou comment un salaire peut être confortable ou ridicule)', LInv, 34:112-37, deals with adjectives expressing a subjective estimate of quantity in, e.g., Ce salaire est bas, ridicule 'Those wages are low'. 
C. Benzitoun, 'Quand Un Corpus rencontre un adjectif du troisième type: Étude distributionnelle de prochain', Corpus, 9:245-64. Pierre-Don Giancarli, *Les Auxiliaires être et avoir: Étude comparée corse, français, acadien et anglais, Rennes U.P., 400 pp. Jorge Juan Vega y Vega, *Qu'est-ce que le verbe être? Éléments de morphologie, de syntaxe et de sémantique, Champion, 275 pp. J. François, 'Construction et Exemplaires: Une Nouvelle Approche des structures prédicatives du français illustrée par la configuration [N s'en V]', Philologie im Netz (online), 58:19-38. Lena Bounaz, The Grammar of French Quantification, Dordrecht, Springer, xii + 260 pp. Sébastien Marengo, *Les Adjectifs jamais attributs: syntaxe et sémantique des adjectifs constructeurs de la référence, Brussels, De Boeck-Duculot, 368 pp. Karen Lahousse, *Quand Passent Les Cigognes: Le Sujet nominal postverbal en français moderne, Vincennes U.P., 296 pp. *LaF, no. 170, 'Unités syntaxiques et unités prosodiques', ed. F. Lefeuvre and Estelle Moline. * LaF, no. 171, 'Détermination et Prédication', ed. Claude Muller and Henning Nølke. C. Fuchs and C. Guimier, “'Les Constructions comparatives intraprédicatives en français', $\operatorname{TrL}, 63: 7-33$. Audrey Roig, * Le Traitement de l'article en français depuis 1980, Oxford, Lang, $238 \mathrm{pp}$.

\section{[H2]6. Lexis, Lexicography, and Lexicology}

*Dictionnaires, Norme(s) et Sociolinguistique, ed. Christophe Rey and Philippe Reynes, L'Harmattan, 362 pp., contains a broad range of papers from events in December 2008 and 2009 , covering for example the history of the creation of the dictionary of the Académie Française, regional and creole dictionaries, spelling reform within contemporary dictionaries, bilingual dictionaries, the handling of borrowings, and child language. A. K. Kaliska, 'Prédicats et Verbes supports d'occurrence météorologiques dans une perspective contrastive francopolonaise', LInv, 34:169-203. B. Peeters, “'Les Faux Amis, une question de degré: L’Apport de 
la métalangue sémantique naturelle', pp. 87-109 of La Marque en lexicographie: États présents, Voies d’avenir, ed. F. Baider et al., Limoges, Lambert-Lucas, 270 pp.

\section{[H2]7. Semantics}

I. Charnavel, 'On Sentence-internal Le Même ('the same') in French and Pluractionality', Going Romance 2009, pp. 55-70, addresses two main issues, definiteness and compositionality, and proposes that le même is a complex determiner with specific properties relating to presupposition and specificity, and an existential quantifier over a plural event partitioned along participants or times. See also Id., 'On French Possessive Son Propre ('his own'): Evidence for an Interaction between Intensification and Binding', Empirical Issues in Syntax and Semantics, 8:53-74.

P. Lauwers and C. Duée, 'From Aspect to Evidentiality: The Subjectification Path of the French Semi-copula se faire and its Spanish Cognate hacerse', JP, 43:1042-60, compare the meaning of the semi-copula meaning 'become' to evidentials like sembler and paraitre 'seem', showing that, although the former expresses indirect evidentiality based on inference, it does not express appearance, having instead a factive meaning similar to what has been called direct evidentiality. Id., 'Se faire/hacerse + attribut: Une Étude contrastive de deux semi-copules pronominales', $R P h, 64: 99-132$.

P. Larrivée, 'What Nominal Phrases are all about: The Atypical Case of Indefinite Pronouns with a Determiner', RF, 121, 2009:3-19, offers an MP-inspired semantic account of the established use of indefinite pronouns with a determiner (ce quelqu'un, du n'importe quoi, un je ne sais quoi) which contravenes assumptions both about pronouns and nominals. M. Lecolle, 'Désadjectivaux formés par conversion et double catégorisation: le cas des adjectifs/noms en -aire', RevR, 46:295-316, sees two kinds of output of this adjective-to-noun 
conversion process, one where the nominal is abstract and has a generic or collective reference, such as l'alimentaire 'alimentary stuff', and one involving ellipsis, where the nominal value is concrete and refers to a class of human individuals or objects. A. Theissen, 'La Quantification verbale: la locution itérative $X$ fois', $R F, 123: 435-53$, addresses the issue of quantification in the verbal domain, more specifically the function of the phrase $X$ fois (Odile a toussé deux/plusieurs fois), cataloguing the variety of item $X$, and considering the (lexical and grammatical) aspectual properties of the VP modified by $X$ fois. V. Lenepveu, 'A première vue, Marqueur d'aspect de dicto', JFLS, 21:381-400, considers the adverbial's semantico-pragmatic function, and the kinds of expression it typically co-occurs with (e.g., à y regarder de plus près).

M. Rosenberg, 'Les Composés français VN: Aspects sémantiques', RevR, 46:69-88. F. Grossman and A. Tutin, *'Evidential Markers in French Scientific W riting: The Case of the French Verb voir', pp. 286-315 of Linguistic Realization of Evidentiality in European Languages, ed. Gabriele Diewald and Elena Smirnova, Berlin, de Gruyter, 2010, vi + 371 pp. M. Aurnague, 'How Motion Verbs are Spatial: The Spatial Foundations of Intransitive Motion Verbs in French', LInv, 34:1-34; Id., 'Quittant tout, nous partîmes: Quitter et Partir à la lumière des changements de relation locative', JFLS, 21:285-312.

\section{[H2]8. Regional French and Dialects}

K. De Keere and M. Elchardus, 'Narrating Linguistic Conflict: A Storytelling Analysis of the Language Conflict in Belgium', Journal of Multilingual and Multicultural Development, 32:221-34, consider how Belgium's two main linguistic groups code each other in stories about living in a bilingual society which were elicited in a storytelling forum and were clearly marked by the history of Belgian linguistic policy, with the Flemish evoking romantic nationalism, and Walloons adopting a more individualistic, practical approach. J. Blommaert, 'The Long 
Language-ideological Debate in Belgium', Journal of Multicultural Discourses, 6:241-56, describes past and present language-ideological debate in Belgium, and seeks to amend the view of the country as one whose political dynamics revolve around language, the fundamental ethnolinguistic difference between Flemish and Walloons, on the grounds that language was never the sole factor in conflicts, but instead was part of a larger democratization process or a power struggle triggered by momentous demographic and socio-economic transformations, and therefore emblematic shorthand for a larger set of issues.

J. S. Nolan, 'Reassessing Gallo as a Regional Language in France: Language Emancipation vs. Monolingual Language Ideology', IJSL, 209:91-112, shows how language emancipation has historical and contemporary relevance to regional languages in the Fr. context of an entrenched monolingual and centralist language ideology vehemently opposed to pluralist language ideology, and particularly how Gallo provides a grass-roots illustration of many of the issues underlying the notion of language emancipation which, if it is to be sociopolitically acceptable, needs to be presented with care.

Using the results from four surveys into language beliefs over a five-year period, R. J. Blackwood, 'Language Beliefs and the Polynomic Model for Corsican', Language Awareness, 20:17-30, evaluates the extent to which islanders engage with the concept of polynomy, and assesses the feasibility of the concept in changing language beliefs and practices, as part of attempts to revitalize the different varieties of Corsican and reverse the language shift to Fr., with speakers, semi-speakers, and non-speakers called upon to recognize the varieties as one language. See also Id., 'The Linguistic Landscape of Brittany and Corsica: A Comparative Study of the Presence of France's Regional Languages in the Public Space', JFLS, 21:111-30, which examines the extent to which two of Fr.'s regional heritage languages mark the public space, detecting trends in the use of Breton and Corsican for different purposes, and differentiating between how cityscapes are marked by those with and without authority. 
Hélène Blondeau, *Cet 'Autres' qui nous distingue: Tendances communautaires et parcours individuels dans le système des pronoms en français québécois, Quebec, Laval U.P., 270 pp., looks at changing group- and individual-level patterns of sociolinguistic variation over the 20th c. between the compound proforms nous autres, vous autres, and eux autres and their simplex counterparts nous, vous, eux, and elles, showing the influence of linguistic, social, stylistic, and temporal factors. D.-E. Bouchard et al., *'Degree Fronting in Québec French and the Syntactic Structure of Degree Quantifier DPs', Going Romance 2009, pp. 39-54, distinguish between two deceptively similar syntactic constructions involving degree adverbs in Québécois (and English): the degree-fronting construction (involving movement) and the intensification-ata-distance construction (no movement; quantifiers base-generated in surface position). In the context of the rise of the periphrastic future at the expense of the inflected future in Québécois French, S. Evans Wagner and G. Sankoff, 'Age Grading in the Montréal French Inflected Future', LVC, 23:275-313, use data from a panel study of 60 Montreal speakers from 1971 to 1984 to challenge the assumption that individual speaker behaviour remains stable over time, demonstrating retrograde age grading, that is, speakers increasing their use of the inflected future as they age, especially in higher socio-economic categories. R. Grimm and T. Nadasdi offer a Labovian sociolinguistic analysis of 'The Future of Ontario French', JFLS, 21:173-89, in adolescent speech, showing how usage of the periphrastic future (elle va partir; cf. the inflected future; elle partira) is markedly higher than in earlier accounts, is in some cases categorical, but that negation is (contra previous findings) not generally a strong usage predictor. P. Comeau and R. King, *'Media Representations of Minority French: Valorization, Identity, and the Acadieman Phenomenon', CanJL, 56:179-202, are concerned with the role of media representations of language use in the promotion of language ideologies and in identity construction, focusing on Chiac, a low-status variety of Acadian Fr., as used by an animated tv character. 
Alexei Prikhodkine, *Dynamique normative du français en usage en Suisse romande: Enquête sociolinguistique dans les cantons de Vaud, Genève et Fribourg, L'Harmattan, 339 pp., is a revised $\mathrm{PhD}$ thesis which considers speakers' linguistic attitudes towards geographic variation, and offers a new perspective on the dynamics of spoken Fr. within Switzerland. Uriel Weinreich, *Languages in Contact: French, German and Romansh in Twentieth-century Switzerland, Amsterdam, Benjamins, xxxiv +401 pp., contains a foreword and a reproduction of W.'s full original 1951 Columbia thesis on language contact along the Fr.-Ger. linguistic border and between Ger.-Romansh in the canton of Grisons, together with fieldwork photographs and hand-drawn diagrams.

Langage et Société, no. 136, 'Appropriation politique et économique des langues', ed. Cécile Canut and Alexandre Duchêne, contains M. Heller 'Du Français comme "droit" au français comme "valeur ajoutée": De La Politique à l'économique au Canada' (13-30) and D. Hall, 'Un Nouveau Projet de dialectologie française: Towards a New Linguistic Atlas of France' $(129-38)$.

\section{[H2]9. Contact and Sociolinguistics}

IJSL, no. 211, 'The Sociolinguistics of Tunisia', ed. Joshua A. Fishman and Ofelia Garcia Otheguy, contains: F. Manzano, 'Le Français en Tunisie, enracinement, forces et fragilités systémiques: Rappels historiques, sociolinguistiques et Brefs Éléments de prospective' (53-81) and K. Walters, 'Gendering French in Tunisia: Language Ideologies and Nationalism' (83-111). I. Diallo, 'Les Défis linguistiques et géopolitiques du français en Afrique au sud du Sahara', Australian Journal of French Studies, 48:34-47, contrasts the post-WWII decline in the use of Fr. in North America, Asia, and Europe with its ongoing growth in post-colonial Africa, and discusses the sociolinguistic and geopolitical challenges facing Fr. in sub-Saharan Africa. 
*Hexagonal Variations: Diversity, Plurality and Reinvention in Contemporary France, ed. Jo McCormack et al., Amsterdam, Rodopi, 469 pp., contains M. Monville-Burston 'Youth Speech au pluriel in the W ritten Press'. Alena Podhorná-Polická, *Universaux argotiques des jeunes: Analyse linguistique dans les lycées professionnels français et tchèques, Brno, Masaryk U.P., 2009, 571 pp., analyses the factors in the emergence and spread of slang lexis among students in Fr. and the Czech Republic, and shows that the commonalities can be accounted for in terms of expressiveness related to psychological factors such as the conscious desire to impress and the unconscious need to speak more intensely, as well as sociological factors such the desire to express bonds within peer groups.

Uniformity and Diversity in Language Policy: Global Perspectives, ed. Catrin Norrby and John Hajek, Clevedon, Multilingual Matters, xx + 312 pp., contains J. Warren and L. Oakes, 'Language Policy and Citizenship in Quebec: French as a Force for Unity in a Diverse Society?' (7-21) and L. Oakes, 'Regional Languages, the European Charter and Republican Values in France Today' (68-85). See also O.'s, 'Promoting Language Rights as Fundamental Individual Rights: France as a Model?', French Politics, 9:50-68. *Language Policy, no. 10.4, 'Language Academies and Management Agencies', ed. Bernard Spolsky, contains D. Estival and A. Pennycook, 'L’Académie française and Anglophone language ideologies' (325-41), which corrects the popular misrepresentation of the Académie Française as a central player in the regulation of Fr., and highlights the role of language ideologies.

*Mougeon Vol. contains an introduction and 16 sociolinguistic studies of language contact in Quebec, western Canada, Fr., and the USA, covering L2 Fr. norms, minority Fr., and speaker perception, with contributors from both sides of the Atlantic. *Deshaies Vol. contains an overview of the sociolinguist's 35-year career working on Québécois and seven articles.

J. Abbou, 'Double Gender Marking in French: A Linguistic Practice of Antisexism', Current Issues in Language Planning, 12:1:55-75, examines the forms of double gender 
marking at typographic, morphosyntactic, and rhetorical levels, and analyses this gender-related language practice as a political tool, used not to standardize linguistic practice, but rather for particular political purposes.

\section{[H2]10. Discourse and Pragmatics}

$J P$, no. 43.10:2477-672, 'Women, Power and the Media', ed. Sylvia Jaworska and Pierre Larrivée, contains three contributions relating to recent Fr. politics: B. Fracchiolla, 'Politeness as a Strategy of Attack in a Gendered Political Debate: The Royal-Sarkozy Debate' (2480-8), G. O'Grady, 'The Unfolded Imagining of Ségolène Royal' (2489-500), and J. Barnes and P. Larrivée, 'Arlette Laguiller: Does the Mainstay of the French Political Far-left Enjoy Linguistic Parity with her Male Counterparts?' (2501-8). L. Lehti, 'Blogging Politics in various Ways: A Typology of French Politicians' Blogs', JP, 43:1610-18, identifies five sub-genres (diary, scrapbook, notice-board, essay, and polemic) within a corpus of 80 politician's blogs based on the criteria of medium, communicative purpose, participant roles, and rhetorical structure.

*Procedural Meaning: Problems and Perspectives, ed. Victoria Escandell-Vidal et al., Bingley, Emerald, 464 pp., contains J. Amenós-Pons, 'Cross-linguistic Variation in Procedural Expressions: Semantics and Pragmatics' (235-66), which contrasts the simple and compound past in Fr. and Sp., concluding that the linguistically underdetermined procedural meaning of each is identical in both languages, while they are associated with different ways of materializing the procedural instruction for each tense, whereby their pragmatically enriched procedural and conceptual meanings taking tendencially divergent inferential paths in each language, and L. de Saussure, 'On Some Methodological Issues in the Conceptual/Procedural Distinction' (55-79), which includes exemplification from Fr. connectives parce que 'because', ensuite and puis 'then' and the Fr. imperfective past tense. See also J. Evers-Vermeul et al., 
'Historical and Comparative Perspectives on Subjectification: A Corpus-based Analysis of Dutch and French Causal Connectives', Linguistics, 49:445-78, which uses two historical and two comparative corpus methods to chart the diachronic development of four causal connectives, Dutch want and omdat and Fr. car and parce que $\sim$ 'because', and to investigate whether subjectification occurs.

A.-L. Tessonneau, 'De la politesse et des usages dans les interactions en Haïti', JP, 43:1512-24, offers a pragmatic analysis of greetings, rites of interaction, and acts of language within a context imbued with symbolism and an importance attached to bodily and linguistic selfcontrol reminiscent of 16 th/17th-c. forms of European courtesy. Birgit Frank, ${ }^{*}$ Aufforderung im Französischen: ein Beitrag zur Geschichte sprachlicher Höflichkeit, Berlin, de Gruyter, xvii + $551 \mathrm{pp}$. , is a study of the phenomenon of linguistic politeness in requests, orders, suggestions, and advice in Fr., showing evidence of a move away from the concept of medieval politeness, based primarily on building up close relationships, to one which takes the personal freedom of the interlocutor into consideration.

J. Carruthers, 'Temporal Framing in the conte: From Theoretical Debate to Oral Story Performance', FS, 65:488-504, addresses the temporal structure of narrative discourse, in particular the role of clause-initial temporal adverbials (dates, relative temporal adverbials, etc.) and temporal 'connectives' like puis and ensuite, concluding that, as with other types of narrative discourse, framing is primarily a structural rather than a temporal device in oral narrative. L. Degand and B. Fagard, 'Alors between Discourse and Grammar: The Role of Syntactic Position', FLang, 18:29-56, focuses on the semantics of the discourse marker alors 'at that time, then, so' and its diachronic development from temporal anaphor to polysemous discourse structuring marker, with a particular interest in its meaning and position in the sentence and the idea that the former is driven by the latter.

D. Maingueneau, 'Multiculturality in Discourse Analysis: The "French" Example', Journal 
of Multicultural Discourses, 6:105-20, presents the approach to discourse analysis rooted in the Fr. cultural intellectual tradition, describing its origins and its main characteristics (a nonempiricist style of research, an interest in non-conversational corpora, a pre-occupation with 'linguistic materiality' and the question of subjectivity in discourse, and the primacy of interdiscourse) and paying special attention to its attitude towards subjectivity. See also Nottingham French Studies, no. 50.2:1-180, 'French Language and Social Interaction: Studies in Conversation Analysis and Interactional Linguistics', ed. Fabienne H. G. Chevalier, which contains an Introduction and 7 articles aiming to make conversation-analysis work on Fr. accessible to a wider audience and covering video football games, left/right dislocation in closing down sequences of talk, and criminal suspect interviews.

S. Pekarek Doehler, *'Clause-combining and the Sequencing of Actions: Projector Constructions in French Talk-in-interaction', pp. 103-48 of Subordination in Conversation: A Cross-linguistic Perspective, ed. Ritva Laury and Ryoko Suzuki, Amsterdam, Benjamins, viii + $244 \mathrm{pp}$, addresses the Je veux dire 'I want to say' + complement clause pattern, the II $y$ a 'there is' presentational cleft construction, and the Ce qui/Ce que ... pseudocleft construction, each comprising the initial 'fragment' followed by a syntactically independent stretch of talk, and shows that these fragments routinely accomplish the social function of projecting upcoming talk, allowing speakers to design their turns in order to help hearers monitor the complex architecture of talk. E. Martin, 'Multilingualism and Web Advertising: Addressing French-speaking Consumers', Journal of Multilingual and Multicultural Development, 32:265-84, draws on quantitative and qualitative data to examine how US companies tailor Web advertising to Fr.speaking consumers around the world, and appeals to the notion of 'language display' to explore strategies involving English borrowings used to appeal to Fr.-speaking audiences. S. Prevost, 'A propos from Verbal Complement to Discourse Marker: A Case of Grammaticalization?', Linguistics, 49:391-413, analyses the pragmatic development of 
preverbal à propos 'by the way' in terms of a discourse marker contributing to coherence, and in relation to à ce propos and à propos de, the latter of which it has in certain contexts progressively replaced. P. Isambert, 'What's on the Left?', Discours (online), 8, investigates how the adverb autrement structures discourse by shifting topic, specifically the devices used to identify which potential topic in the left context is actually being shifted. L. Mayol and E. Castroviejo, 'Unfortunate Questions: Evaluative Adverbs in Questions in French', Going Romance 2009 , pp. 223-38, examine the semantic properties of evaluative adverbs like unfortunately when used in yes-no/wh questions. Beate Kern, *Metonymie und Diskurskontinuität im Französischen, Berlin, de Gruyter, 2010, x + 265 pp., analyses the interaction of metonymy and discourse environment in extracts from Fr. news magazines. Christiane Maaß, *Diskursdeixis im Französischen: eine korpusbasierte Studie zu Semantik und Pragmatik diskursdeiktischer Verweise, Berlin, de Gruyter, 2010, xiii +373 pp., derives a new theory of discourse deixis, reference to parts or aspects of the ongoing discourse and/or text, based on the identification and classification of discourse-deictic references in multi-genre corpora.

M. Salles, ‘Que présuppose l'anaphore dite présuppositionnelle? Sur La Coréférenciation des expressions nominales complètes', JFLS, 21:191-208. K. Mullan, 'Une Entente glaciale? French and Australian English Interaction', Explorations: A Journal of FrenchAustralian Connections, 50:16-36. B. S. Gillon, *'French Relational Words, Context Sensitivity and Implicit Arguments', pp. 143-63 of Making Semantics Pragmatic, ed. Ken Turner, Bingley, Emerald, 240 pp. *LaF, no. 172, 'Ponctuation(s) et architecturation du discours à l'écrit', ed. Michel Favriaud. FM, no. 79.1:1-128, 'Figures de l'à-peu-près: en hommage à Ronald Landheer', ed. Alain Rabatel.

\section{[H2]11. Computer-mediated communication}


E. Stark, 'La Morphosyntaxe dans les SMS suisse francophones: Le Marquage de l'accord sujet-verbe conjugué', Linguistik Online, 48, shows, first, that subject-verb agreement marking in text messages is closer to standard orthography with lexical subjects (albeit rare) and, second, that this type of typologically and theoretically central type of agreement is marked in one way or another in some $90 \%$ of occurrences, suggesting that the core grammar remains intact in 'non-standard' texts. S. Doehler, 'Hallo! Voulez vous luncher avec moi hüt? Le "Code switching" dans la communication par SMS', Linguistik Online, 48, shows how Francophone Swiss SMS users regularly change language even if they are not members of a bilingual speech community, with code-switching most frequently comprising insertion of a limited range of single/combined items mainly but not exclusively from English, and Sp. and It. items being particularly associated with terms of endearment. R. van Compernolle, 'Use and Variation of French diacritics on an Internet Dating Site', JFLS, 21:131-48, shows age and gender to be significant social variables in the use of Fr. accents and diacritics in electronic personal ads, and offers explanations in terms of the eventual loss of accents and diacritics in computer-mediated French, stable variation with differences between 'digital natives' and 'digital immigrants', and a change in progress whereby accents and diacritics are becoming 'prestige variants' in computer-mediated contexts.

The place of publication of books is Paris unless otherwise stated. 
Berrendonner Vol.: Du Système linguistique aux actions langagières: Mélanges en l'honneur d’Alain Berrendonner, ed. Gilles Corminboeuf and Marie-José Béguelin, Brussels, De Boeck-Duculot, $672 \mathrm{pp}$.

Deshaies Vol:: Hétérogénéité et Homogénéité dans les pratiques langagières: Mélanges offerts à Denise Deshaies, ed. Wim Remysen and Diane Vincent, Quebec, Laval U.P., 236 pp.

Martin Vol.: La Logique du sens: Autour Des Propositions de Robert Martin, ed. Frédéric Duval, Metz, Paul Verlaine U.P., 330 pp.

Meisel Vol.: The Development of Grammar: Language Acquisition and Diachronic Change: In Honour of Jürgen M. Meisel, ed. Esther Rinke and Tanja Kupisch, Amsterdam, Benjamins, viii + 414 pp.

Mougeon Vol.: Le Français en contact: Hommages à Raymond Mougeon, ed. France Martineau and Terry Nadasdi, Quebec, Laval U.P., 460 pp.

LSRL 40: Romance Linguistics 2010: Selected Papers from the 40th Linguistic Symposium on Romance Languages (LSRL), Seattle, Washington, March 2010, ed. Julia Herschensohn, Amsterdam, Benjamins, xvii $+332 \mathrm{pp}$.

Going Romance 2009: Romance Languages and Linguistic Theory 2009: selected papers from 'Going Romance', Nice, 2009, ed. Janine Berns et al., Amsterdam, Benjamins, viii + 393 pp. 